\title{
IN VITRO EVALUATION OF ENZYMIC ANTIOXIDANTS AND FREE RADICAL SCAVENGING ACTIVITY IN THE ETHANOLIC EXTRACT OF CRESCENTIA CUJETE LEAVES
}

\author{
ANITHA $P^{1 *}$, NAZEEMA TH ${ }^{2}$ \\ ${ }^{1}$ Department of Biochemistry, Rathnavel Subramaniam College of Arts and Science, Coimbatore, Tamil Nadu, India. ${ }^{2}$ Department of \\ Michael Job College of Arts and Science for Women, Coimbatore, Tamil Nadu, India. Email: sai.anithabiochem@gmail.com
}

Received: 07 January 2019, Revised and Accepted: 10 Febrauary 2020

\section{ABSTRACT}

Objectives: This study aims to evaluate the enzymic antioxidants and free radical scavenging present in the ethanolic leaf extracts of Crescentia cujete.

Methods: Enzymic antioxidants such as superoxide dismutase (SOD), catalase (CAT), glutathione reductase, glutathione peroxidase, and glutathione S-transferase (GST) were estimated by standard methods. Free radical scavenging potential was evaluated by diphenylpicrylhydrazyl (DPPH), nitric oxide, and hydroxyl radical methods using an ethanolic extract of $C$. cujete leaf.

Results: The leaf extract of $C$. cujete showed the maximum activity of CAT, SOD, GST, glutathione reductase, and peroxidase activity. CAT activity was formed to be highest in the ethanolic extract of $C$. cujete leaf. DPPH radical scavenging activity was reported as $38.5 \mu \mathrm{g} / \mathrm{ml}$, nitric oxide was found to be $200.77 \mu \mathrm{g} / \mathrm{ml}$, and hydroxyl radical scavenging exhibited $108.42 \mu \mathrm{g} / \mathrm{ml}$ normalized with ascorbic acid.

Conclusion: From the results, it has concluded that the ethanol extract of the $C$. cujete leaf has a prospective source of natural antioxidant that would be a great significance as therapeutic agents in preventing or slowing the progress of reactive oxygen species and related oxidative stress-related degenerative diseases.

Keywords: Crescentia cujete, Enzymic antioxidants, Free radical scavenging.

(C) 2020 The Authors. Published by Innovare Academic Sciences Pvt Ltd. This is an open access article under the CC BY license (http://creativecommons. org/licenses/by/4. 0/) DOI: http://dx.doi.org/10.22159/ajpcr.2020.v13i4.36794

\section{INTRODUCTION}

Medicinal plants play a key role in well-being of $80 \%$ of the world's population for their primary health benefits [1]. The medicinal plants have strong antioxidant activity and may help to protect the cells against the oxidative damage caused by free radicals. These free radicals and reactive oxygen species (ROS) such as superoxide anion, hydroxyl radical, and hydrogen peroxide play an essential role in the progress of various ailments such as arthritis, asthma, dementia, carcinoma, and Parkinson's disease [2].

Calabash, Crescentia cujete L. (Family Bignoniaceae), is a tree found in the West Indies, tropical America, and tropical areas of the world [3]. C. cujete is a smooth, much-branched tree growing to a height of 4-5 m. Branches are arching with close-set clusters of leaves and lanceolate with the more pointed end of the base, 5-17 cm long and glossy at the upper surface [4].

C. cujete tree obtain various health benefits, such as anti-inflammatory, antibacterial, antivenom, central nervous system depressant, and wound healing properties [5]. Plants produce numerous bioactive compounds for protecting nervous tissues from the damage caused by oxidative stress and many of them act as antioxidants [6]. Therefore, the aim of the present study was to analyze the enzymic antioxidant and free-radical scavenging ability of the ethanolic extract of $C$. cujete leaf.

\section{METHODS}

\section{Plant collection}

The leaves of $C$. cujete were collected from Anakkatti, Coimbatore, and authenticated by the voucher specimen (No: BSI/SRC/5/23/2017/ Tech 2021) at the Botanical Survey of India (BSI), Coimbatore.

\section{Plant sample extraction}

The air-dried leaves of $C$. cujete were pulverized into powdered form. The dried powder $(0.5 \mathrm{~g})$ of the samples was extracted by soaking with ethanol using an orbital shaker for $48 \mathrm{~h}$ at room temperature. The residues used for the analysis are obtained from the solvents from the combined extracts which were evaporated using a vacuum rotary evaporator.

\section{Assay of antioxidants in C. cujete ethanolic leaf extract}

Estimation of enzymatic antioxidants

The ethanol extract of the leaves of $C$. cujete was analyzed for the presence of enzymatic antioxidants by adopting standard protocols. Enzymic antioxidants include superoxide dismutase (SOD) [7], catalase (CAT) [8], peroxidase [9], glutathione S-transferase (GST) [10], and glutathione reductase [11] methods.

\section{Diphenylpicrylhydrazyl (DPPH) radical scavenging assay}

DPPH react with antioxidants to form diphenyl-picryl hydrazine. The quantity of discoloration from purple to yellow color was measured at $518 \mathrm{~nm}$, which is an assess of the scavenging potential of antioxidant extracts. $0.4 \mathrm{mM}$ of ethanol solution of DPPH was added with $20 \mu \mathrm{l}$ of different solvent extracts of different concentrations ranging from $20 \mu \mathrm{g}$ to $100 \mu \mathrm{g} / \mathrm{ml}$. The mixture was shaken vigorously and allowed to stand at room temperature for $30 \mathrm{~min}$. Ethanol served as blank. DPPH in ethanol without the leaf extracts served as positive control. Standard used as ascorbic acid and an experiment was done in triplicate. Then, absorbance was measured at $518 \mathrm{~nm}$ using a spectrophotometer (UVVIS Shimadzu) [12]. The higher free radical potential indicates the lesser absorbance of the reaction mixture [13]. The percent DPPH scavenging effect was calculated using the following equation: DPPH scavenging effect $(\%)$ or Percent inhibition $=A_{0}-A_{1} / A_{0} \times 100$.

\section{Nitric oxide radical scavenging assay}

The nitric oxide scavenging activity was calculated according to the former described method [14]. Sodium nitroprusside $(10 \mathrm{mM})$ in phosphate buffered saline was mixed with different concentrations of the ethanol extract of $C$. cujete and incubated at $25^{\circ} \mathrm{C}$ for $150 \mathrm{~min}$. 
The samples were then mixed with Griess reagent (1\% sulfanilamide, $2 \%$ phosphoric acid, and $0.1 \% \mathrm{~N}$-(1-naphthyl) ethylenediamine dihydrochloride). The absorbance of the chromophore produced during diazotization of nitrite with sulfanilamide and consequent coupling with NED was read at $546 \mathrm{~nm}$ using a spectrophotometer. The inhibition of nitric oxide development was compared with respect to standard potassium nitrite in the same way with Griess reagent.

\section{Hydroxyl radical scavenging assay}

The tubes containing reaction mixture were covered firmly and kept in a water bath at $80-90^{\circ} \mathrm{C}$ for $15 \mathrm{~min}$, the reaction mixture contained $1.0 \mathrm{ml}$ of different concentration of extracts $(2-10 \mathrm{mg} / \mathrm{ml}), 1.0 \mathrm{ml}$ of iron-ethylenediaminetetraacetic acid (EDTA) solution $(0.13 \%$ ferrous ammonium sulfate $0.26 \%$ EDTA), $0.5 \mathrm{ml}$ of $0.018 \%$ EDTA, $1.0 \mathrm{ml}$ of dimethyl sulfoxide $(0.85 \%$ in $0.1 \mathrm{~mol} / \mathrm{L}$ phosphate buffer $\mathrm{pH} 7.4)$, and $0.5 \mathrm{ml}$ of $0.22 \%$ ascorbic acid and this reaction was completed by adding $1.0 \mathrm{ml}$ of ice cold trichloroacetic acid (17.5\%) and for the color development $3.0 \mathrm{ml}$ of Nash reagent was added into the reaction mixture incubated at room temperature for $15 \mathrm{~min}$. The yellow color developed was read at $412 \mathrm{~nm}$ against a reagent blank. Ascorbic acid was used as standard. The percentage of inhibition was determined by comparing test with the standard [15].

\section{RESULTS}

\section{Enzymatic antioxidants of $C$. cujete leaves}

In the present study, the SOD activity of $C$. cujete leaves extract was found to be $26.90 \pm 1.16 \mathrm{U} / \mathrm{g}$. The level of CAT $125.18 \pm 0.98 \mathrm{U} / \mathrm{g}$ exhibited significant activity in the enzymatic antioxidant group. Peroxidase activity for $C$. cujete leaves extract was found to be $31.53 \pm 1.21 \mu$ moles of pyrogallol oxidized/min. The activity of glutathione reductase in C. cujete leaves extract was observed as $10.75 \pm 0.86 \mu$ moles of NADPH oxidized/min/g sample. Leaf extract found to possess effective GST activity $12.55 \pm 0.49 \mu$ moles of CDNB-GSH conjugate $/ \mathrm{min} / \mathrm{g}$. These results are in accordance with the enzymic antioxidants in the seed and leaf samples of Syzygium cumini and Momordica charantia [16].

The total assessment of enzymatic antioxidant activity of $C$. cujete is noted to be effective, as shown in Table 1.

- SOD - Amount that causes a 50\% reduction in the extent of NBT oxidation

- CAT - Amount of enzyme required to decrease the optical density by 0.05 units

- Peroxidase $-\mu$ moles of pyrogallol oxidized/min

- Glutathione reductase - $\mu$ moles of NADPH oxidized/min/g sample

- GST $-\mu$ moles of CDNB-GSH conjugate/min/g sample.

Scavenging activity of the ethanol extract of $C$. cujete leaves (values are averages of triplicate experiment and are represented as mean \pm standard error $[\mathrm{SE}])$.

Scavenging activity of the ethanol extract of $C$. cujete leaves (values are averages of triplicate experiment and are represented as mean \pm SE).

Scavenging activity of ethanol extract of $C$. cujete leaves (values are averages of triplicate experiment and are represented as mean $\pm \mathrm{SE}$ ).

In this study, ethanolic $C$. cujete leaf crude was taken as $20-100 \mu \mathrm{g} / \mathrm{ml}$ concentration, produced a dose-depended scavenging of DPPH radicals. The results showed that the scavenging effect increases with an increase in the concentration of samples. The activity of ethanolic $C$. cujete leaf crude was compared with standard ascorbic acid and the maximum scavenging effects of DPPH radical were obtained at $75.8 \%$ of inhibition in $250 \mu \mathrm{g} / \mathrm{ml}$ and the IC $_{50}$ values were found to be $38.5 \mu \mathrm{g} / \mathrm{ml}$, as shown in Fig. 1. The similar findings in DPPH radical scavenging activity reported in different parts of S. cumini [17].

Nitric oxide radical scavenging effects of the ethanolic extracts are represented in Fig. 2, which showed the existence of free radical. The
Table 1: Enzymatic antioxidants of Crescentia cujete leaves

\begin{tabular}{lll}
\hline S. No & Enzymatic antioxidants & $* \mathbf{U} / \mathbf{g}$ \\
\hline 1. & Superoxide dismutase & $26.90 \pm 1.16$ \\
2. & Catalase & $125.18 \pm 0.98$ \\
3. & Peroxidase & $31.53 \pm 1.21$ \\
4. & Glutathione reductase & $10.75 \pm 0.86$ \\
5. & Glutathione-s-transferase & $12.55 \pm 0.49$ \\
\hline
\end{tabular}

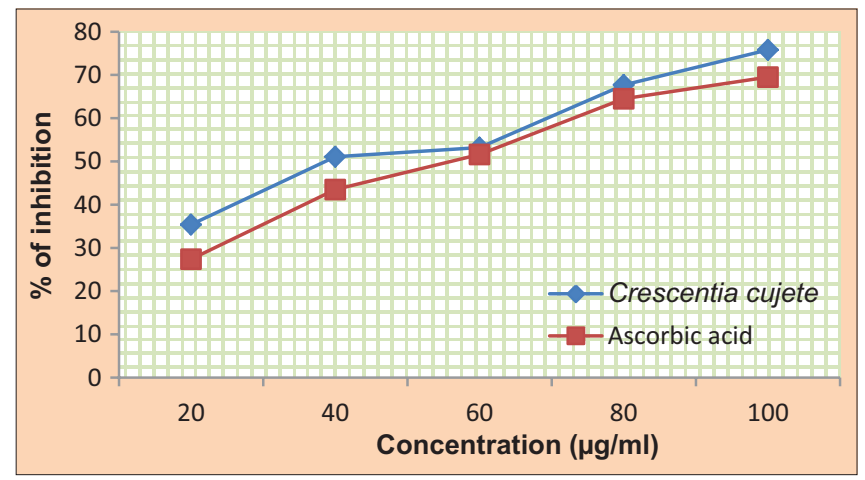

Fig. 1: DPPH radical scavenging activity in the ethanolic leaf extract of Crescentia cujete

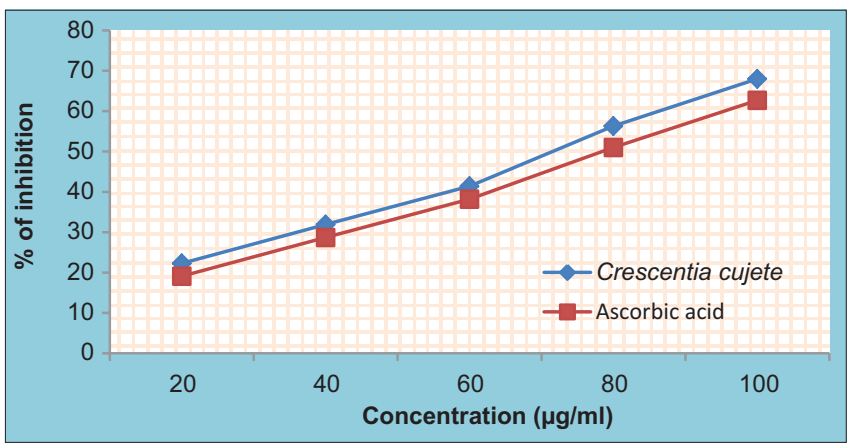

Fig. 2: Nitric oxide radical scavenging activity in the ethanolic leaf extract of Crescentia cujete

inhibition of nitric oxide radical suggested that the ethanolic extract caused considerable dose-dependent scavenging effect and was compared with that of the reference compound ascorbic acid, which is also represented in their respective $\mathrm{IC}_{50}$ values of the ethanolic extract and standard ascorbate $(200.77$ and $149.50 \mu \mathrm{g} / \mathrm{ml})$. This result is in line with an earlier study of antioxidant potential in ethanolic seed extract of Ficus benghalensis Linn seed [18].

Leaf extracts exerted inhibition against $\mathrm{OH}$ - formation during the incubation period. $82 \pm 0.92 \%$ inhibition was observed in the ethanolic extract of $C$. cujete leaf. However, standard ascorbate was found to possess $52.13 \%$ scavenging activity which was lower than the $C$. cujete leaf. This assay shows that consistent increase in the concentration of the ethanolic extracts of $C$. cujete leaf has an increased hydroxyl radical scavenging activity (Fig. 3 ). The $\mathrm{IC}_{50}$ values of the ethanolic extract and standard in this assay were found to be 108.42 and $52.13 \mu \mathrm{g} / \mathrm{ml}$, respectively. The methanolic leaves extract of Azima tetracantha showed good hydroxyl scavenging of free radicals which supported our observations [19].

\section{DISCUSSION}

The enzymatic antioxidants estimation conducted on the leaf extract of $C$. cujete revealed the presence of antioxidant enzymes that are known to play a key role in maintaining optimal cellular and systemic health and wellbeing [20]. It has been discovered that the intake of 


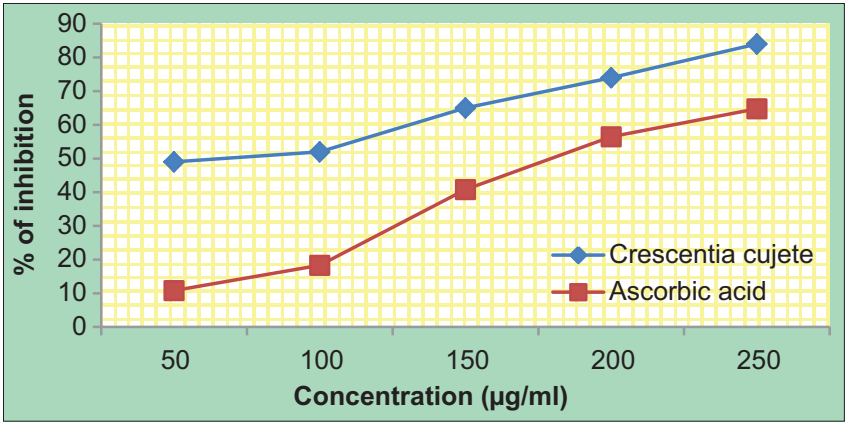

Fig. 3: Hydroxyl radical scavenging activity in the ethanolic leaf extracts of Crescentia cujete

antioxidant from plant sources lowers the chances of cardiovascular diseases, cancers [21], and neurodegenerative diseases [22]. SOD is ubiquitous metalloenzymes, which become involved in cellular defense against ROS in living organisms; hence, it is an important indicator of antioxidant defense system in plant cells against ROS toxicity [23]. CAT is a protein, with four heme groups which protect the cell from oxidative damage by catalyzing the dismutation of hydrogen peroxide in water and oxygen [24]. Peroxidase is an oxidoreductase antioxidant particularly important for brain involved in the detoxification of free radicals such as hydrogen and lipid peroxides and protects the cells from damage [25].

Glutathione reductase is important to note that shifting the reduced glutathione/oxidized glutathione redox toward the oxidizing state activates several signaling pathways, thereby reducing cell production and increasing programmed cell death [26]. Thus, oxidative stress (a deleterious imbalance between the production and removal of reactive oxygen/nitrogen species) plays a key role in the pathogenesis of many diseases, including cancer, Alzheimer's disease, Parkinson's disease, sickle cell anemia, liver disease, and diabetes. GST are multifunctional proteins which are important in maintaining -SH groups in other molecules, including proteins, regulating thiol-disulfide status of the cell, and detoxifying foreign compounds and free radicals [27].

As the observations made with the ethanolic extract of $C$. cujete leaf with analysis of enzymic antioxidants, it shows importance to study the free radical Scavenging activity.

Antioxidants with DPPH radical scavenging activity could provide hydrogen to free radicals, particularly to the lipid peroxides or hydroperoxide radicals that are the major initiators of the chain autoxidation of lipids, and to form independent existence containing one or more unpaired electrons, resulting in the inhibition of propagating phase of lipid peroxidation. The level of discoloration reveals the ability of compounds as free-radical scavengers or hydrogen donors and to evaluate the antioxidative potential of the ethanolic extract of $C$. cujete leaf [28].

Nitric oxide is denoted as a free radical because of its unpaired electron and displays significant reactivity with other free radicals. The toxicity of NO becomes adverse when it reacts with superoxide radical, forming a highly reactive peroxynitrite anion and these compounds are responsible for altering the structural and functional behavior of many cellular components [29]. Antioxidants donate protons to the nitrite radical, the absorbance is decreased. The decrease in absorbance was used to measure the extent of nitrite radical scavenging [30]. Ethanol extracts of $C$. cujete reduced the generation of $\mathrm{NO} \bullet$ in a concentrationdependent manner as the nitric oxide scavenging property of all the concentration was found to be better than the standard ascorbic acid.

The hydroxyl radical is the most ROS and causes rigorous damage to neighboring biomolecule The hydroxyl radicals were formed by the oxidation reaction with the dimethyl sulfoxide to yield formaldehyde, which provides a suitable method to identify hydroxyl radicals by reacting with Nash reagent [31]. The hydroxyl radical scavenging activity of the leaf extracts of $C$. cujete shows the quenching ability of hydroxyl radicals, which seems to be a good scavenger of active oxygen species thus reduce the rate of chain reaction. The scavenging property of the hydroxyl radicals may be due to the existence of antioxidants in the $C$. cujete extract.

\section{CONCLUSION}

The current study established that the ethanolic extract of $C$. cujete leaf acquired potential enzymic antioxidants and free radical scavenging which leads to be a favorable in prevention of various oxidative stress-related diseases; hence, it is essential for identifying the phytocompounds to identify their pharmacological properties.

\section{AUTHORS' CONTRIBUTIONS}

AP made a significant contribution to the performing the assays, acquisition of data and writing the manuscript and THN participated in the design of the experiment.

\section{CONFLICTS OF INTEREST}

The authors declared that they have no conflicts of interest.

\section{AUTHORS FUNDING}

Authors contribute equally.

\section{REFERENCES}

1. Ho YS, So KF, Chang RC. Anti-aging herbal medicine-how and why they can be used in aging associated neurodegenerative diseases? Ageing Res Rev 2010;9:54-362.

2. Halliwell B, Gutteridge JM. Role of free-radicals and catalytic metal ions in human disease: An overview. Methods Enzymol 1990;186:1-85.

3. Sturtevant EL. Sturtevant's Edible Plants of the World. New York Department of Agriculture 27 $7^{\text {th }}$ Annual Report. Part 2. Albany, New York: J. B. Lyon Company; 1991

4. Parvin MS, Das N, Jahan N, Akhter MA, Nahar L, Islam ME. Evaluation of in vitro anti-inflammatory and antibacterial potential of Crescentia cujete leaves and stems bark. BMC Res Notes 2015;8:412.

5. Dawodu OA, Lawal OA, Ogunwande IA, Giwa AA. Volatile constituents of Crescentia cujete L. Am J Essent Oil Nat Prod 2016;4:1-3.

6. Virmani A, Pinto L, Binienda Z, Ali S. Food, nutrigenomics, and neurodegeneration-neuroprotection by what you eat! Mol Neurobiol 2013;48:353-62.

7. Misra HP, Fridovich I. The role of superoxide anion in the autoxidation of epinephrine and a simple assay for superoxide dismutase. J Biol Chem 1972;247:3170-5.

8. Luck H. Methods of Enzymatic Analysis. Cambridge: Academic Press; 1974. p. 885-94.

9. Reddy KP, Subhani SM, Khan PA, Kumar KB. Effect of light and benzyl adenine and desk treated growing leaves, changes in the peroxidase activity. J Cell Physiol 1995;26:984.

10. David M, Richard JS. Verlag chemie, weinheim; deerfield beach, florida. In: Bergmeyer J, Mariare GB, editors. Methods of Enzymatic Analysis. Amsterdam: Elsevier; 1983. p. 358

11. Habig WH, Pabst MJ, Jocoby WB. Glutathione S-transferase: The first enzymatic step in mercapturic acid formation. J Biol Chem 1974;249:7310-39.

12. Koleva II, van Beek TA, Linssen JP, de Groot A, Evstatieva LN. Screening of plant extracts for antioxidant activity: A comparative study on three testing methods. Phytochem Anal 2002;13:8-17.

13. Achola KJ, Munenge RW. Bronchodilating and uterine activities of Ageratum conyzoides extract. Pharm Biol 1998;36:93-6.

14. Ebrahimzadeh MA, Nabavi SF, Nabavi SM. Antioxidant activities of methanol extract of sambucusebulus L. Flower. Pak J Biol Sci 2009; $12: 447-50$

15. Nabavi SM, Ebrahimzadeh MA, Nabavi SF, Jafari M. Free radical scavenging activity and antioxidant capacity of Eryngium caucasicum Trautv and Froripia subpinnata, Pharmacol Res 2008;3:19-25.

16. Sharmila R, Pushpa A. In vitro evaluation of enzymic antioxidants in the seed and leaf samples of Syzygium cumini and Momordica charantia. Int J Sci Res Publ 2015;5:476-80. 
17. Bhati GS, Vaidya X,Sharma P,Agnihotri A.Evaluation of phytochemicals and free radical scavenging behavior in different parts of Syzygium cumini. Int J Curr Pharm Res 2017;9:180-5. Avilable from:https://www.innovareacademics.in/journals/index.php/ ijc pr/article/view/22183.

18. Govindan V, Shoba FG.Qualitative and quantitative determination of secondary metabolites and antioxidant potential of Ficus benghalensis Linn seed. Int $\mathrm{J}$ Pharm Pharm Sci 2015;7:118-24.Avilablefrom:https://www.innovareacademics.in/jou rnals/index.php/ijpps/article/view/5925.

19. Gopalakrishnan GB, Nair NR,Babu V.Scavenging of free radicals and total phenols of methanol extract of Azima tetracantha Lam.Int J Pharm Pharm Sci 2014;6:347-51. Avilable from https://www.innovareacademics.in/journals/index.php/ijpps/article/184

20. Ebrahimzadeh MA, Pourmorad F, Hafezi S. Antioxidant activities of Iranian corn silk. Turk J Biol 2008;32:43-9.

21. Kris-Etherton PM, Hecker KD, Bonanome A, Coval SM, Binkoski $\mathrm{AE}$, Hilpert $\mathrm{KF}$, et al. Bioactive compounds in foods: Their role in the prevention of cardiovascular disease and cancer. Am J Med 2002;113 Suppl 9B:71S-88S

22. Di Matteo V, Esposito E. Biochemical and therapeutic effects of antioxidants in the treatment of Alzheimer's disease, Parkinson's disease, and amyotrophic lateral sclerosis. Curr Drug Targets CNS Neurol Disord 2003;2:95-107.

23. Sudipta KM, Swamy MK, Balasubramanya S, Anuradha M. Assessment of genetic fidelity, antioxidant enzyme activity and proline content of micropropagated and field grown plants of Leptadenia reticulata (Wight and Arn.) An endangered medicinal plant. Plant Cell Biotechnol Mol Biol 2014; 15:127-35.

24. Panchawat S, Sisodia SS. In vitro antioxidant activity of Saraca asoca Roxb. De wilde stem bark extracts from various extraction processes. Asian J Pharm Clin Res 2010;3:231-3.

25. Ragavendran P, Arul Raj C, Sophia D, Starlin T, Gopalakrishnan VK. Evaluation of enzymatic and non-enzymatic antioxidant properties of Aerva lanata (L)-an in vitro study. Int J Pharm Pharm Sci 2012;4:522-6.

26. Sen CK. Cellular thiols and redox-regulated signal transduction. Curr Top Cell Regul 2000;36:1-30.

27. Valko M, Leibfritz D, Moncol J, Cronin MT, Mazur M, Telser J. Free radicals and antioxidants in normal physiological functions and human disease. Int J Biochem Cell Biol 2007;39:44-84.

28. Porto CD, Calligaris S, Celloti E, Nicoli MC. Antiradical properties of commercial cognacs assessed by the DPPH(.) test. J Agric Food Chem 2000;48:4241-5

29. Nagmoti DM, Khatri DK, Juvekar PR, Juvekar AR. Antioxidant activity and free radical-scavenging potential of Pithecellobium dulce Benth seed extracts. Free Radic Antioxid 2011;2:37-43.

30. Turkoglu A, Duru ME, Mercan N, Kivrak I, Gezer K. Antioxidant and antimicrobial activities of Laetiporus sulphureus (Bull.) Murrill. Food Chem 2007;101:267-3

31. Duan X, Wu G, Jiang, Y. Evaluation of the antioxidant properties of litchi fruit phenolics in relation to pericarp browning prevention. Molecules 2007;12:759-71. 